\title{
The Development of Chemical Bonding Module Based on Science Generic Skill
}

\author{
I Nyoman Sudyana, Deklin Frantius \\ Faculty of Teacher Training and Education \\ Universitas Palangka Raya \\ Palangka Raya, Indonesia \\ pr1.unparkalteng@gmail.com,
}

\begin{abstract}
General chemistry is needed as a foundation for further understanding. One of the general chemistry concepts is the chemical bonding. Subtopics of chemical bonding selected in this study were: (1) electronegativity, (2) the Lewis' structure, (3) formal charge, (4) resonance concept, (5) octet rule, (6) bond energy, (7) geometry molecule, (8) dipole, (9) valence bond theory, (10) hybridization, and (11) molecular orbital theory. Based on the characteristics, learning the chemical bonding concepts needs an understanding of the scale, symbolic language, framework of logic, consistency of logic, inference of logic, causal, and modeling, so the development of learning materials based on Science Generic Skills (SGS) is really important. In this research, material development model adopted 4-D Thiagarajan, which consisted of define, design, developed, and disseminate. The draft was validated by two content experts and one media expert using the questionnaires. The phase of legibility test was carried out by individual and group of students who had taken courses on General Chemistry I. The developed product was Chemical Bonding Module Based on Science Generic Skill. The results showed that the feasibility test of the content was $81.5 \%$. Based on empirical tests in Chemistry Education Study Program at the Universitas Palangka Raya, the legibility of the individual and group were respectively $80.0 \%$ and $79.4 \%$. The results showed that the developed module can be used as an alternative learning material.
\end{abstract}

Keywords-Chemical Bonding, Module, Science Generic Skill

\section{INTRODUCTION}

Basic chemistry is prerequisite and a center of science, in particular to the field of chemistry [1] [2] [3] [4]. The basic chemistry concept is very important to understand as a whole [5]. Basic chemistry is the interpretation of a general principle based on data analysis of experimental results and it requires logical approaches and understanding of mathematics [6][7]. Logical approach is used to explain the pattern of consistency, inference, logical framework, and causality of empirical data while mathematical comprehension is used as the support of mathematical concepts such as the balance or scale formula. Visualization of logic and mathematics in basic chemical form of symbolic representation [8]. Basic chemistry also represents the characteristic of the material in the form of microscopic modeling [9].

Based on the characteristics described by the experts, studying the basic chemistry requires logical consistency skill, logical inference, causality, logical framework, understanding scale, modeling, and the symbolic language. Those skills are included in the skill of science generic (KGS) component [10].

KGS skill is still a weakness from the side of the students in which $56.3 \%$ of second semester students of Chemistry Department Malang Univeristy assumed that voltaic cells will still produce electricity when the salt bridge is replaced with a Pt wire. Students conclude that electricity will still occur because the Pt wire is the conductor. Their conclusions indicate that the skills to understand the causality has not been right [11].

The results of another study showed $50.0 \%$ fifth semester students of the Department of Chemical Education PMIPA FKIP Universitas Lambung Mangkurat, Banjarmasin, stated that strong acid does not dissociate in water. That answer was not appropriate because strong acid always dissociates in water solvent. Strong acid characteristic which is always dissolve in water is consistent based on the experiment facts. According to Arrhenius, strong acid dissociates in water produces $\mathrm{H}^{+}$ions. Therefore, understanding the logical consistency of the students is still weak [12].

The observation results at the Department of Chemistry Education PMIPA FKIP Universitas Palangka Raya, Central Kalimantan were as follows: (1) $46,7 \%$ of students' answers in the test of acid-base was still incorrect in writing the notation of equation reaction of $\mathrm{HCI}$ gas dissolving process in water based on acid-base concept of Arrhenius. The students wrote the reaction equation without including the phase symbol (g), (aq), (l) and (s). This fact suggests that the symbolic language of students is still low, and (2) the lecturers explained that there were still many students who did not yet understand well the material of Basic Chemistry I and II. Empirical facts showed learning results from middle test and final test are still low for the Basic Chemistry I and II course [13].

The data of the last four years, middle test and final test result of class offering 2011 to 2014 in course of Basic Chemistry I and II showed that there were still many students who have not reached the minimum value of 55.5 or did not pass. The average percentages of students who did not pass were as follows: (1) 25.7 for class of 2011 ; (2) 41.1 for class of 2012; (3) 23.1 class of 2013; and (4) 26.8 for class of 2014. The low learning results for the Basic Chemistry I and II course can obstruct the students to study chemistry in further 
level. Therefore, the basic chemistry instructional design needs to be developed in accordance with the basic chemical characteristics oriented with KGS.

KGS is a basic ability with general characteristic, flexible, and orientation as a preparation to study a higher level of science [14]. Students with good generic skills are expected to be more adaptable and achieve learning success [15]. KGS is the basic thing that helps the process of creative and critical thinking, decision making, and problem solving in daily life [16]. The learning which is training generic skill can improve learning outcomes [15][17][18]. Based on the experts, instructional design which is KGS oriented in basic chemistry can improve student learning achevement.

The instructional design should train the generic skills [19, 20]. Teaching chemistry concept should be designed with the orientation of KGS. Students are trained to think based on data to find the concept. The data are obtained from the results of experiments and analyzed. Analysis requires reasoning abilities of students. Reasoning train students to find consistency logic, logic framework, logical inference, causality, scale, and symbolic language based on the data. The activities of reasoning are steps to guide students to arrange the concept independently. Studying chemistry also requires modeling capabilities. Modeling capabilities is very necessary to present abstract concepts into more tangible form. Therefore, KGS needs to be designed in the learning process.

The learning process will occur if there is a communication between the receiver and the source of the message [21]. Between the receiver and the source of the message, there is an instructional media. Instructional media has a function as an intermediary. Instructional media is expected to serve as a messenger for good learning. Messages are learning objectives to be achieved. Instructional media messages are sources of learning.

The main source of learning for students of Chemistry Education Department PMIPA FKIP Universitas Palangka Raya, Central Kalimantan, which is following the Basic Chemistry I course is a book with informative material [13]. Delivery of basic chemistry concepts has not been trained with KGS. The concept is directly supplied without a guidance to analyze the data first. For example, Lewis structural modeling to represent a compound covalently bonded is directly written. The students are not guided to analyze the data as the basis for the appearance of the concept of a covalent bond. Also, the learning materials are displayed through PowerPoint presentation and handout has not served to train the students to think inductively. The concept is directly provided and is not arranged to guide the students to process the data as the basis for drawing conclusions independently. The students tend to be passive and do not treat the lecturers as a facilitator. The lecturers directly explain the data, issues, and conclusions. The students tend to memorize the material and do not practice to increasing KGS.

Based on observations, the source of student learning in Basic Chemistry I course still has some deficiencies as follows. (1) It does not guide students to learn independently. (2) There is no feedback so that the level of student understanding is not yet known. (3) It does not accommodate students who require a longer learning time. (4) The formulation of learning objectives have not given explicitly, so that the students do not know the learning objectives have been achieved. (5) It is informative, yet it is not inductive which means the concept is directly awarded without guiding students to analyze and to process the data as the basis for drawing conclusions. (6) The material is not oriented to practice symbolic language skills, consistency, inference, framework, causality, scale, and modeling. Therefore, the characteristics of instructional media that needs to be developed is to accommodate independent learning, feedback, individual differences, the formulation of learning objectives, inductive, and improve KGS.

The module is an instructional media [22]. The module allows students to learn independently [23][24]. Learning using the module also provides a more flexible learning time [17]. KGS orientation is arranged in modules to train students to make observations, comprehension, reasoning, and independent modeling with more flexible time study. Opportunities to learn independently and more flexible learning time are necessary because each student has different characteristics. Self-learning method allows students to learn in accordance with the time and speed required [25]. Module should be developed because it is relevant to the students' characteristics.

The module can also be used in a large class. According to [26], if a class exceeds 40 students, it can be classified as a large classroom. One of instructional media that is suitable for a large class is module. Chemistry Education Department PMIPA FKIP Universitas Palangkaraya, Central Kalimantan, has one Basic Chemistry class. The number of students who will take Chemistry I course is more than 40 people in one class. Based on the condition of the class, the module is one of the instructional media that should be used in Basic Chemistry course.

One example of empirical studies is conducted by [27]. Her study proved that the use of the modules on the electrochemical material with multimedia models for applied courses can improve learning outcomes of students on refrigeration and air conditioning in the Engineering Department of Mechanical Engineering Polytechnic of Bali by $42.8 \%$. Students' learning outcomes were improved significantly after the module was given as an instructional media. Another study also demonstrated the use of the module and $\mathrm{CD}$ for Organic Chemistry I course audio-visual based to enhance understanding of $93.0 \%$ in the students from class of 2012 of Chemistry Department PMIPA IAIN Walisongo, Semarang [28]. Research on the use of the modules was conducted by [23]. The results showed that the use of the modules in the course of optical waves proved a positive influence learning outcomes. Students from class of 2008 in Physics Education Department FMIPA University of Surabaya passed as much as $80.0 \%$. Several studies have shown that the use of the module as an instructional media for students has a positive effect on learning results. Therefore, modules can be developed as a source of learning in basic chemistry course.

Basic chemistry course is divided into two parts: Basic Chemistry I and II. One of the basic chemistry materials is chemical bond. The ability to interpret the electronegativity 
value is based on Pauling scale which requires comprehension skills scale. Identifying the chemical compounds polar and non-polar require symbolic language skills are necessary in this case. Logical reasoning is also necessary to understand the chemical bond and to explain the relationship electronegativity, dipole moment, and the polarity of a molecular logic skills framework. Students are expected to show inference data as the basis emergence of the concept of covalent bonds. Skills of describing causality are needed when explaining differences in polarity of a species. Modeling skills are also required to interpret the shape of the molecule. Based on these characteristics, chemical bonding requires KGS-oriented learning activities. Therefore, KGS-oriented modules need to be developed on the material of chemical bonds of Chemistry I course.

Research on the development which of learning design is KGS-oriented empirically is proven to have a positive impact. Research conducted by [16] showed that the design of KGS integrated learning produce n-gain score students of Chemistry Education Department, University of Semarang about 0,39. The use of KGS-oriented module provides the average value of n-gain score that is 0.36 on the students of Chemistry Education Department, University of Makassar [29]. Other research also concluded that the acid-base concept module KGS oriented empirically proven to be improved the average n-gain score KGS about 0.58 [13].

Based on the previous explanation about the use of KGSoriented module in learning, students are expected to practice the skills of understanding scale, symbolic language, logic framework, the consistency of logic, causality, and modeling students. Modules for chemical bonding material which is KGS oriented has never been developed. Therefore, it is necessary to do research and development of chemical bonding module which is KGS oriented at Chemistry Education Department PMIPA Universitas Palangka Raya, Central Kalimantan.

\section{METHOD}

The development of module for chemical bonding material adopted the 4-D development model [30]. 4-D Model of Thiagarajan was selected because it contained measures in accordance with the purposes of research and development base module. The study was designed to modify the procedure of Thiagarajan's model.

The research was focused on the definition, design, and development, while the development stage of deployment was not done. Figure 1 shows fishbone diagram of development research steps module.

Instrument used in the study was a questionnaire. Questionnaire compiled by referring to [31]. Questionnaire contains a series of questions and the response by the respondent. The questionnaire consisted of expert assessment and student questionnaires compiled based on the Likert scale with category selection. It can be seen in Table 1 .
TABLE I. ASSESSMENT SCALE AND CATEGORIES IN THE QUESTIONAIRE

\begin{tabular}{|c|c|c|c|}
\hline \multicolumn{4}{|c|}{ Score } \\
\hline $\boldsymbol{1}$ & $\mathbf{2}$ & $\mathbf{3}$ & $\mathbf{4}$ \\
\hline $\begin{array}{c}\text { Fair/decent/ } \\
\text { clear/easy/ } \\
\text { proper/ } \\
\text { appropriate }\end{array}$ & $\begin{array}{c}\text { Good/decent/ } \\
\text { clear/easy/ } \\
\text { proper/ } \\
\text { appropriate }\end{array}$ & $\begin{array}{c}\text { Very } \\
\text { good/decent/clear/ } \\
\text { easy/proper/ } \\
\text { appropriate }\end{array}$ & $\begin{array}{c}\text { Excellent/ } \\
\text { decent/clear/ } \\
\text { easy/proper/ } \\
\text { appropriate }\end{array}$ \\
\hline
\end{tabular}

The questionnaire consisted of expert assessment and student assessment. The questionnaire was used to determine the assessment of experts on the feasibility of an instrument developed. The instruments were rated by experts such as modules draft, test questionnaire, and legibility modules. Student assessment questionnaire was used to determine the students' perception about the feasibility of modules developed. Perceptions of students were asked in two phases: (1) perception of the individual readability was a stage to require an assessment for 3 students to using questionnaire and (2) perception of readability test group was the stage of knowing the assessment of 15 students based on the format of the questionnaire provided.

Validators were involved to give an assessment. The validators consisted of two material experts and a media expert. Validator criteria for material experts who have been selected in the research and development were: (1) mastering concepts in the course of Chemistry, (2) having a minimum master degree, (3) being a lecturer who teaches chemistry, and (4) understanding the descriptions of Generic Science Skills. The total number of validators involved was three lecturers.

Design of the first revision was the result of the improvement of previously developed module. Design of the first revision was based on expert assessment. The results of design of revision I were subsequently used on individual readability test stage.

Individual testing aimed to test the readability level module development on design of revisions I. The students provided an assessment to the design of revision I based on the questionnaire. The data of exam result of Chemical Bond course were analyzed. This step aimed to determine the student rankings in order to obtain top rankings, middle rankings, and bottom rankings. Ranking used to determine the 15 participants representing students were achievement of over, middle, and bottom level.

Determined criteria as a basis to choose student to individual readability test were as flollows: (1) has been following the Basic Chemistry I course, (2) a sixth semester student of Chemistry Education Department PMIPA FKIP Universitas Palangka Raya, (3) has been getting pretest, (4) represents the students in high rate capability, middle, and low based on test results, and (5) willing to thoroughly examine and give value feasibility modules. Design of revision II was the result of the improvement of revision I. Design of revision II was developed based on the student assessment individual readability test 


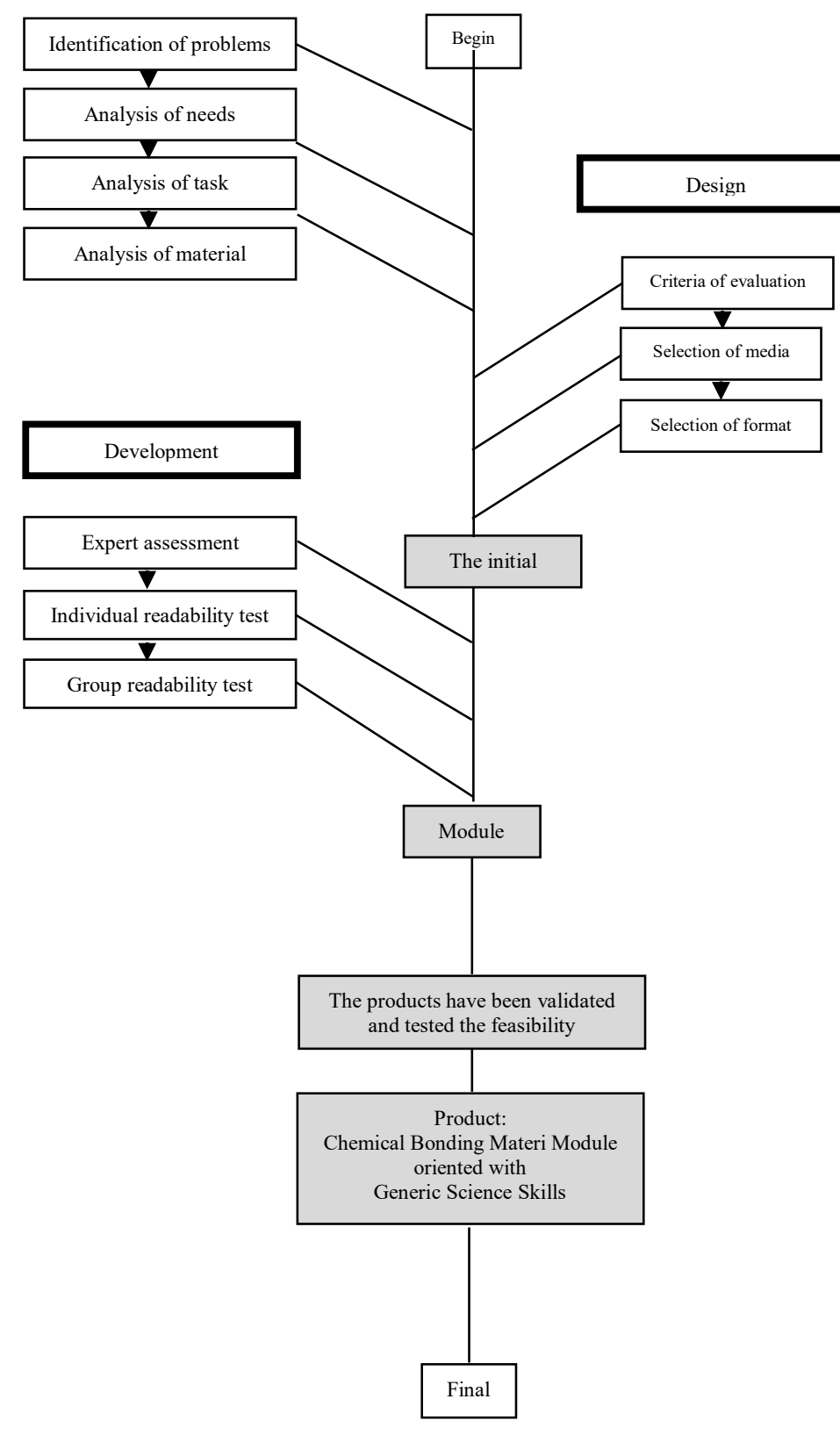

Fig. 1. Fishbone diagram development research steps of the module

Group readibility test involved 50 students. Group readibility test aimed to reexamine the readability level of design of revision II. Design of revision III was the result of the improvement of the design of revision II. Design of revision III was based on assessment on group readibility test.

Expert assessment questionnaire was intended to measure the validity of the instrument. The data from expert assessment questionnaire were scored and suggestions for improvement of validatorwere given. Student assessment questionnaire consisted of a questionnaire for individual and group readibility test. Individual readability test questionnaire by students was used to examine the readability of revision result module I and group readability test to examine the readability of revision result for module II. The questionnaire was needed to be validated before being used as a measurement instrument of readability module on the individual readability test and group readability test. The formula to calculate the validity of using average calculation is as follows:

$$
P=\frac{\sum x}{\sum x_{1}} \times 100 \%
$$

Where are $\mathrm{P}=$ percentage, $\Sigma X=$ sum score of the assessor, and $\sum X_{1}=$ highest total score

According to the research design that uses one class, the prerequisite test analysis conducted is a normality test. Normality test was used to determine if the data analyzed were normally distributed or not. The test was calculated using SPSS 16.0 for Windows. The data were distributed normally if the significance valuewas greater than 0.05 and were not distributed normally if the significance value was less than 0.05 . Normality test was done on the data from pretest and posttest.

Descriptive qualitative analysis was done based on the opinions and suggestions of experts and students. Descriptive quantitative analysis was based on data obtained from the questionnaire. Descriptive quantitative analysis aimed to determine the feasibility of the module. Categories of feasibility for the percentage of modules can be seen in Table 2.

TABLE II. FEASIBILITY LEVEL MODULE ${ }^{[32]}$

\begin{tabular}{|c|c|c|}
\hline Feasibility Level (\%) & Category & Information \\
\hline $80-100$ & Decent & No need revision \\
$60-79$ & Fairly decent & No need revision \\
$40-59$ & Less decent & Need revision \\
$0-39$ & Not decent & Need revision \\
\hline
\end{tabular}

\section{RESULT AND DISCUSSION}

The products that have been compiled still required the validation process. Validation was done to improve product quality. Table 3 is an explanation of expert validation data. Validated products were draft module. Improvements based on the validation experts were used to produce revision I. The average score of the feasibility level of the Module, Individual Readability Test Questionnaire, and Group Readability Test Questionnaire were $81.5 \%$; 75.0\%; and $85.0 \%$, respectively. Based on the criteria listed in Table 2, the feasibility level of the Module, Individual Readability Test Questionnaire, and Group Readability Test Questionnaire were respectively categorized as very decent, decent, and very decent. Therefore, the research instrument can be used for group trials.

TABLE III. EXPERT VALIDATION FOR PRODUCT DEVELOPMENT AND QUESTIONNAIRE

\begin{tabular}{|l|c|c|}
\hline \multicolumn{1}{|c|}{ Aspects Assessed } & Average Percentage (\%) & Category \\
\hline Module & 81.5 & Very decent \\
Individual Readability Test & 75.0 & Decent \\
Questionnaire & 85.0 & Very decent \\
Group Readability Test & & \\
Questionnaire & & \\
\hline
\end{tabular}


Empirical test of product development was necessary to know the feasibility of module for users. In this case, the students acted as the users. Readability test has been done in two stages. The first stage was individual readability test and the second stage was group readability test. The readability test recapitulation is summarized in Table 4.

Fifteen students who were involved in the group readability test were given three days to evaluate the revised I module. Individual readability test results are listed in Table 4. Based on Table 4, the module was categorized as decent.

\section{TABLE IV. ASSESSMENT RESULTS OF READABILITY TEST} MODULE

\begin{tabular}{|c|c|c|}
\hline Readability & Average Percentage (\%) & Category \\
\hline Individual & 80.0 & Decent \\
Group & 79.4 & Decent \\
\hline
\end{tabular}

The number of students involved in group trials was 50 . The module given to the students was the result of revision II. At this stage, the students were given one week to evaluate the module. The data of readability test module in group readability trials can be seen in Table 4 . The results of the group readability test showed that the module was categorized as very decent to use as an alternative of teaching materials. This is accordance with the opinions of experts that KGS can improve student learning outcomes [14, 15, 16, 17, 18].

\section{CONCLUSION}

Product result of this research and development is a module. The module design was oriented to seven KGS components namely symbolic language, causality, logical consistency, scale comprehension, logical inference, logic framework, and modeling. The seven components of KGS can be trained on chemistry learning. One of them is chemical bonding material because it has the relevant characteristics.

Module readability was evaluated in three stages: (1) expert test, (2) individual readability test, and (3) group readability test. The results from expert test were very decent, decent, and very decent categorized. The result from individual readability test was decent categorized. The result from group readability test was decent categorized. Based on the results of three stages, it is concluded that the developed module can be used as an alternative learning material.

\section{REFERENCES}

[1] R. J. Duchovic, "Teaching College General Chemistry: Techniques Designed to Communicate a Conceptual Framework", Journal of Chemical Education, 75(7): 856-857, 1998.

[2] L. S. Forster, "General Education and General Chemistry", Journal of Chemical Education. 83: 614-616, 2006.

[3] J. S. Francisco, G. Nicoll, and M. Trautmann, "Integrating Multiple Methods into a General Chemistry Classroom", Journal of Chemical Education, 75(2): 210-213, 1998.

[4] N. J. Pienta, "Teaching general chemistry and making a difference', Journal of Chemical Education, 91: 305-306, 2014.

[5] D. Hanson and T. Wolfskill, "Improving the teaching or learning process in general skill”, Journal of Chemical Education, 75(2): 143-146, 1998.
[6] J. A. Olmsted and M. G. Williams, Chemistry (4 ${ }^{\text {th }}$ Edition), John Willey \& Sons, Inc, 2005.

[7] M. S. Silberberg, Principles of General Chemistry, New York: McGraw-Hill, 2007.

[8] T. R. Gilbert, R. V. Kirss, N. Foster and G. Davies, Chemistry: The Science in Context, New York: W. W. Norton \& Company, 2009.

[9] P. G. Hewitt, S. Lyons, J. Suchocki, and J. Yeh, Conceptual Integrated Science, San Francisco: Pearson Education, Inc, 2007.

[10] M. Sekarwinahyu dan D. Mustafa, Hakikat Pembelajaran MIPA dan Kiat Pembelajaran Kimia, Jakarta: PAU-PPAI-UT, 2001.

[11] E. Y. Heriyana, Menggali Pemahaman Mahasiswa Angkatan Tahun Pertama FMIPA Universitas Negeri Malang dalam Pokok Bahasan Elektrokimia Menggunakan Isntrumen Diagnostik Two-Tier, Universitas Negeri Malang, 2013, unpublished.

[12] A. Winarti, Analisis Pemahaman Konsep Asam Basa Melalui Penggambaran Mikroskopis dan Hubungannya dengan Kemampuan Berpikir Formal Mahasiswa Program Studi Pendidikan Kimia FKIP Unlam Banjarmasin. Universitas Negeri Malang, 1998, unpublished.

[13] D. Frantius, Pengembangan Modul Konsep Asam Basa Berorientasi Ketrampilan Generik Sains, Universitas Negeri Malang, 2016, unpublished.

[14] P. D. Bailey, "Teaching chemist to communicate? Not my job", Chemistry Education, 5: 80-86, 2001.

[15] E. Johnson, S. Herd, and J. Tisdall, "Encouraging generic skill in science courses", Electronic Journal of Biotechnology, 5(2), 2002.

[16] Sudarmin, "Meningkatkan Kemampuan Berpikir Mahasiswa Melalui Pembelajaran Kimia Terintegrasi Kemampuan Generik Sains", Prosiding Seminar Nasional Pendidikan dan Penerapan MIPA, hal. 114-123, 2009.

[17] H. Fry, S. Ketteridge, and S. Marshall, A Handbook for Teaching and Learning in Higher Education, New York: Routledge, 2009.

[18] M. Tight, Researching Higher Education, United Kingdom: Bell \& Bain, Ltd., 2003.

[19] J. Hoddinott \& D. Young, "Generic skills teaching in material science and engineering", Journal of Engineering Education, pp. 707-711, 2001.

[20] S. Yassin, F. A. Hasan, A. Amin, \& N. Amirudin, "Implementation of Generic Skills in the Curriculum", Proceedings of the EDU-COM 2008 International Conference, hal. 571-582, 2008.

[21] R. Susilana, Media Pembelajaran. Bandung: Wacana Prima, 2007.

[22] R. M. Gagne \& L. J. Briggs, Principles of Instructional Design ( $2^{\text {nd }}$ Edition), United States: Holt, Rinehart, \& Winston, 1979.

[23] M. Mulyaratna, S. Mulyaningsih, \& T. Sunarti, "Upaya Meningkatkan Kemampuan Mahasiswa Belajar Mandiri Melalui Pengembangan Modul Mata Kuliah Gelombang Optik di Program Pendidikan Fisika FMIPA Unesa", Prosiding Seminar Nasional Penelitian Pendidikan dan Penerapan MIPA, hal. 383-387, 2011.

[24] E. Mulyasa, Kurikulum yang Disempurnakan, Bandung: PT Remaja Rosdakarya, 2004.

[25] L. Budiardjo, Hakikat Metode Instruksional, Jakarta: PAU-PPAI-UT, 2001

[26] A. Gintings, Esensi Praktis Belajar dan Pembelajaran, Bandung: Humaniora, 2008.

[27] I. A. A. Arsani, Pengembangan Modul Kimia Berbasis Multimedia untuk Mahasiswa Jurusan Teknik Mesin Politeknik Negeri Bali, Universitas Negeri Malang, 2014, unpublished.

[28] U. Hasanah, Pengembangan Modul dan CD Pembelajaran Kimia Organik Berbasis Audio Visual pada Stereokimia: Alkana, Sikloalkana, dan Alkena, IAIN Walisongo, Semarang, 2013, unpublished.

[29] L. Ramlawati and A. R. Wulan, "Pengembangan model asesmen portofolio elektronik (ape) untuk meningkatkan keterampilan generik sains mahasiswa", Jurnal Chemica, 13: 31-41, 2012.

[30] S. Thiagarajan, D. S. Semmel, and M. I. Semmel, Instructional Development for Training Teachers of Exceptional Childrean: A Sourcebook, Washington: National Center for Improvement of Educational Systems, 1974.

31] BSNP, Panduan Penyusunan Kurikulum Tingkat Satuan Pendidikan Jenjang Pendidikan Dasar dan Menengah, Jakarta: Depdiknas, 2006.

32] S. Arikunto, Dasar-dasar Evaluasi Pendidikan, Jakarta: Bumi Aksara, 2003. 